\title{
CORRELATION OF CELL PROLIFERATION WITH CERVICAL LYMPHOID NODE STATUS IN NASOPHARYNGEAL CARCINOMA PATIENTS
}

\author{
Puguh Setyo Nugroho ${ }^{1 *}$, Muhtarum Yusuf ${ }^{2}$, Titiek H Ahadiah $^{2}$ \\ ${ }^{1}$ Universitas Airlangga Hospital / Department of Ottolaryngology Head and Neck Surgery, Faculty of Medicine, \\ Universitas Airlangga, Surabaya, Indonesia, ${ }^{2}$ dr. Soetomo Academic Hospital / Department of Ottolaryngology \\ Head and Neck Surgery, Faculty of Medicine, Universitas Airlangga, Surabaya, Indonesia
}

\section{ABSTRACT}

Several studies showed that the index of nasopharyngeal carcinoma (NPC) cell growth could be used to assess the carcinogenesis interaction factor, development and prognosis of NPC. Cell proliferation index could always be assessed with Ki-67 protein expression test. This research was conducted to study the correlation between cell proliferation index with cervical lymphoid node status in NPC in clinical manifestation to asses the progressivity and prognosis on NPC patients. This study used cross sectional design. Biopsy tissue specimen were acquired from 35 NPC patients clinically divided into four criteria of cervical lymphoid node status (NO, N1, N2 and N3). Expression of Ki-67 protein was acquired by immunohistochemistry test using monoclonal rabbit antibody anti-human Ki-67 clone 901-325-091911 (Biocare Medical, LCC. 4040 Pike Line, CA 94520 USA). The measurement of Ki-67 protein was conducted by pathology consultant. Spearman statistic test was performed to asses the correlation between Ki-67 protein expression and cervical lymphoid node status. The statistical significance was defined as $p<0.05$. Positive expression of Ki-67 protein was found in 33 patients; 4 patients with N0 (11.43\%), 5 patients with N1 (14.29\%), 9 patients with N2 (25.71\%), and 15 patients with N3. Negative expression of Ki-67 protein was found in 2 patients with NO (5.71\%). The Spearman test resulted at $p=0.0001$ with correlation coefficient of 0.758 . The correlation between Ki-67 protein expression with cervical lymphoid node resulted in a significant correlation ( $p<0.05)$. In conclusion, cell proliferation index has correlation with cervical lymphoid node status in NPC patients.

Keywords: nasopharyngeal carcinoma (NPC); cell proliferation index; Ki-67 protein expression; cervical lymphoid node status

\section{ABSTRAK}

Beberapa penelitian menunjukkan indeks proliferasi sel pada penderita karsinoma nasofaring (KNF) dapat digunakan untuk menilai faktor interaksi karsinogenesis, perkembangan dan prognosis KNF. Indeks proliferasi sel dapat dinilai dengan ekspresi protein Ki-67. Penelitian dilakukan untuk mengetahui hubungan antara indeks proliferasi sel dengan status kelenjar getah bening (KGB) KNF untuk menilai progresivitas dan prognosis penderita KNF. Penelitian ini menggunakan desain cross sectional. Spesimen jaringan biopsi diperoleh dari 35 penderita $K N F$, secara klinis dibagi menjadi empat kriteria status KGB (NO, N1, N2 dan N3). Ekspresi protein Ki-67 diperoleh dengan uji imunohistokimia menggunakan antibodi rabbit monoklonal anti-human klon Ki-67 901-325-091911 (Biocare Medical, LCC 4040 Pike Line, CA 94520 USA). Penilaian protein Ki-67 dilakukan oleh konsultan patologi anatomi. Uji statistik spearman digunakan untuk menilai korelasi antara ekspresi protein Ki67 dan status KGB. Signifikansi statistik ditentukan sebagai p <0,05. Ekspresi positif protein Ki-67 pada 33 pasien; 4 pasien dengan NO (11,43\%), 5 pasien dengan N1 (14,29\%), 9 pasien dengan N2 (25,71\%) dan 15 pasien dengan N3. Ekspresi negatif protein Ki-67 pada 2 pasien dengan NO (5,71\%). Uji Spearman menghasilkan $p=0,0001$ dengan koefisien korelasi 0,758. Korelasi antara ekspresi protein Ki-67 dengan status KGB menghasilkan korelasi yang signifikan (p<0,05). Sebagai simpulan, indeks proliferasi sel berhubungan dengan status KGB pada penderita KGB.

Kata kunci: karsinoma nasofaring; indeks proliferasi sel; ekspresi protein Ki-67; status KGB servikal

Correspondence: Puguh Setyo Nugroho, Universitas Airlangga Hospital / Department of Ottolaryngology Head and Neck Surgery, Faculty of Medicine, Universitas Airlangga, Surabaya, Indonesia. Email: puguh-sn@fk.unair.ac.id

pISSN:2355-8393 • eISSN: 2599-056x • doi: 10.20473/fmi.v57i1.8765

- Fol Med Indones. 2020;57:20-26• Received 2 Jul $2018 \bullet$ Accepted 22 Jan 2018

- Open access under CC-BY-NC-SA license • Available at https://e-journal.unair.ac.id/FMI/ 


\section{INTRODUCTION}

The general prognosis of nasopharyngeal carcinoma (NPC) is currently based on the assessment of clinical stadium by assessing primary tumor (T), cervical metastatic nodule $(\mathrm{N})$ and widespread metastasis $(\mathrm{M})$. Nasopharyngeal carcinoma patients with equal clinical stadium, but different prognosis are still frequently found. This shows that the TNM evaluation still unable to provide the accurate prediction to the prognosis of NPC. According to this issue, the development to molecular biomarker in NPC is required to be done to evaluate malignancy progressment that can help clinicians in performing interventional treatment in NPC patients and increase prognostic prediction ( $\mathrm{Li}$ et al 2008).

One of the biomedical indicator that can be used to evaluate progressivity and prognosis of NPC is by measuring the cell proliferation index (Taweevisit et al 2010). Researches were conducted to analyze the correlation between the enlargement of cervical lymphoid node and cell proliferation index to determine the prognosis of NPC patients (Lin 2010, Taweevisit 2007).

Cell proliferation comprises of cell division and cell growth. The cell cycle is underlying the mechanism and regulation of cell proliferation. The proliferation activity of a cell can be determined by counting the mitotic index, proliferating cell nuclear antigen (PCNA) and expression of $\mathrm{Ki}-67$ protein. Inspection of $\mathrm{Ki}-67$ protein expression was recommended because it was being expressed along the cell cycle except during G0 phase (Eccles 2011, Kresno 2012).

Zhuxin and Shaofeng in 2002 conducted a research on the correlation between cell proliferation index and cervical lymphoid node status in NPC patients acquiring a significant result and can be used as a prognostic indicator for NPC patients (Zhuxin \& Shaofeng 2013). Shi et al (2005) and Liu et al (2007) conducted the same research and acquired the same result (Liu et al 2008, Shi et al 2005). By contrast, a study which was conducted by Taweevisit et al 2010 in Thailand, acquired a non-significant correlation between cell proliferation index and cervical lymphoid node status in NPC patients (Taweevisit et al 2010). Likewise, Ozel et al in 2004 in Turky also conducted the same research with non-significant result. The differences in result show that there is still an uncertainty in the correlation between cell proliferation index and cervical lymphoid node status in NPC patients (Ozel et al 2004).

High cell proliferation index correlates with bad prognosis. High cell proliferation index shows progesivity of cancer cell growth which in turn has invasive nature and tendency to be metastatic. The evaluation of proliferation index can be used as concideration for interventional therapy and evaluate growth or reduction in tumor mass after chemotherapy and radiotherapy to evaluate respond to the therapy (Taweevisit et al 2010, Lin 2010, Piris \& Mihm 2007, Aswarin 2014, Le \& Lu 2010, Harahap 2009).

Some malignancies such as limphoma, breast cancer, endometrium cancer, prostate cancer, gastric cancer, NPC and other use cell proliferation index can be utilized to evaluate progressivity and prognostic. Based on the explanation above, there is a need to conduct a study in terms of finding the correlation between cell proliferation index and cervical lymphoid node status that hopefully can be useful to estimate the progressivity and prognosis of NPC patients and used as consideration material to provide intervention therapy to NPC patients.

\section{MATERIALS AND METHODS}

This study was an analytical observational research with cross sectional approach. This study was to evaluate the cell proliferation index in NPC patients, to evaluate and to explain the correlation between cell proliferation index with cervical lymphoid node status in NC patients. The study was conducted in Otorhinolaryngology-Oncology OPD Dr. Soetomo Academic Hospital Surabaya from April 2014 until December 2014 with the NPC patients who came to be treated (Medical Records Data in 2014).

The inclusion criteria of this study were NPC patients which had not receive definitive therapies, namely radiotherapy and chemotherapy. The NPC patients without enlargement of cervical lymphoid node were described as N0. Meanwhile, NPC patients with cervical lymphoidnode enlargement were described as N1, N2 and N3.

The exclusion criteria of this study were patients who did not have histopathological sample in the form of paraffin block from nasopharyng biopsy materials that had enough tumor tissue (4 micron in thickness) to be cell proliferation tested. The variables of this research are independent and dependent variable. The independent variable of this research is the cell proliferation index, while the dependent variable of this research is cervical lymphoid node status.

The inspection of cervical lymphoid node status was conducted and gathering a large number of patient samples for each criteria of cervical lymphoid node (N0, N1, N2 and N3) as can be seen in Table 1. 
Table 1. Cervical lymphoid node criteria

\begin{tabular}{ll}
\hline Stadium & Description \\
\hline $\mathrm{N}_{0}$ & No enlargement of cervical lymphoid node \\
$\mathrm{N}_{1}$ & If there is an enlargement of unilateral cervical lymphoid node, $\leq 6 \mathrm{~cm}$, above supraclavicular fossa, \\
& and/or unilateral or bilateral, retrofaringlymphoid node $\leq 6 \mathrm{~cm}$, with large size \\
$\mathrm{N}_{2}$ & $\begin{array}{l}\text { If there is an enlargement of bilateral cervical lymphoid node, } \leq 6 \mathrm{~cm} \text { at the biggest size, above } \\
\text { supraclavicular fossa }\end{array}$ \\
$\mathrm{N}_{3}$ & If enlargement of cervical lymphoid node $>6 \mathrm{~cm}$, and/or heading toward supraclavicular fossa is present \\
\hline
\end{tabular}

The selection of nasopharyng tissue from NPC patients and assessment of cell proliferation index by looking at Ki-67 protein expression was performed with immunohistochemistry technique using rabbit antihuman monoclonal antibody Clone 901-325-091911 (Biocare Medical, LCC 4040 Pike Line, CA 94520 USA), then assessment was done toward the expression of Ki-67 protein by anatomical pathologist consultant in the anatomical pathology installation of Dr. Soetomo Academic Hospital Surabaya. Cell proliferation index was counted by looking at the number of cells which express Ki-67 monoclonal antibody which then marked by a brown coloured nucleus. The assessment of Ki-67 protein expression was done by determining hot spot areas using microscope with 100 times magnification. The chosen hot-spot areas then manually counted the expression of Ki-67 which was coloured brown in the nucleus when observed with microscope using 400 times magnification, then presentation of cells which positively expressed $\mathrm{Ki}-67$ protein was measured (Taweevisit 2007). Expression of Ki-67 protein was differentiated into 5 assessment scores as seen in Table 2 .

Table 2. Ki-67 protein expression levels score

\begin{tabular}{ll}
\hline Score & Annotation \\
\hline Negative & $\begin{array}{l}\text { Brown granules in the nucleus occur in less than }(<) 10 \% \text { from all field of view with } 400 \text { times } \\
\text { magnification. }\end{array}$ \\
Positif 1 & $\begin{array}{l}\text { Brown granules in the nucleus occur in between } 10 \% \text { and } 25 \% \text { from all field of view with } 400 \\
\text { times magnification. }\end{array}$ \\
Positive 2 & $\begin{array}{l}\text { Brown granules in the nucleus occur in between } 26 \% \text { and } 50 \% \text { from all field of view with } 400 \\
\text { times magnification. }\end{array}$ \\
Positive 3 & $\begin{array}{l}\text { Brown granules in the nucleus occur in between } 51 \% \text { and } 75 \% \text { from all field of view with } 400 \\
\text { times magnification. } \\
\text { Positive } 4\end{array}$ \\
& $\begin{array}{l}\text { Brown granules in the nucleus occur in more than } 75 \% \text { from all field of view with } 400 \text { times } \\
\text { magnification. }\end{array}$ \\
\hline
\end{tabular}

Source: Taweevisit et al (2010), Taweevisit (2007), Shi et al (2005), Ozel et al (2004)

Acquired data was analyzed statistically. Spearman statistic test was used to determine correlation between cell proliferation indexes with cervical lymphoid node status in NPC patients. Significant level (alpha) $=0.05$.

\section{RESULTS}

There were 35 gathered samples that fulfill the criteria from NPC patients. Distribution data of NPC patients were found based on cervical lymphoid node status and $\mathrm{Ki}-67$ protein expression.

Table 3. Distribution of cervical lymphoid node status

\begin{tabular}{lll}
\hline Cervical Lymphoid Node Status & $\mathrm{N}$ & $\%$ \\
\hline $\mathrm{N}_{0}$ & 6 & 17.14 \\
$\mathrm{~N}_{1}$ & 5 & 14.29 \\
$\mathrm{~N}_{2}$ & 9 & 25.71 \\
$\mathrm{~N}_{3}$ & 15 & 42.86 \\
\hline Total & 35 & 100.00 \\
\hline
\end{tabular}

Table 3 showed that there were 6 patients without cervical lymphoid node enlargement (17.14\%) and 29 patients with enlargement $(82.86 \%)$. Patients with N3 cervical lymphoid node status were the most abundant which were 15 patients $(42.86 \%)$ followed by N2 with 9 patients $(25.71 \%)$.

Table 4. Ki-67 protein expression distribution

\begin{tabular}{lll}
\hline Ki-67 protein expression & $\mathrm{N}$ & $\%$ \\
\hline Negative & 2 & 5.71 \\
Positive 1 & 10 & 28.57 \\
Positive 2 & 13 & 37.14 \\
Positive 3 & 5 & 14.29 \\
Positive 4 & 5 & 14.29 \\
\hline Total & 35 & 100.00 \\
\hline
\end{tabular}

Table 4 showed distribution of cell proliferation index by evaluating $\mathrm{Ki}-67$ protein expression, negative value were found in 2 patients $(5.71 \%)$ and positive in 33 patients $(94.29 \%)$. The positive value with the largest amount is positive 2 at 13 NPC patients (37.14\%) 
followed by positive 1 at 10 NPC patients $(28.57 \%)$ and positive 2 and 3, each at 5 patients $(14.29 \%)$.

Table 5. Ki-67 protein expression test result based on cervical lymphoid node status (N0, N1, N2, N3)

\begin{tabular}{llllllll}
\hline Ki-67 score & $\mathrm{N}_{0}$ & $\mathrm{~N}_{1}$ & $\mathrm{~N}_{2}$ & $\mathrm{~N}_{3}$ & Total & $\%$ & Result \\
\hline Negative & 2 & 0 & 0 & 0 & 2 & 5.71 & $\mathrm{p}=0.0001$ \\
Positive 1 & 4 & 3 & 2 & 1 & 10 & 28.57 & $\mathrm{r}=0.758$ \\
Positive 2 & 0 & 2 & 6 & 5 & 13 & 37.14 & \\
Positive 3 & 0 & 0 & 1 & 4 & 5 & 14.29 & \\
Positive 4 & 0 & 0 & 0 & 5 & 5 & 14.29 & \\
Total & 6 & 5 & 9 & 15 & 35 & 100.00 & \\
\hline
\end{tabular}

$* \mathrm{P}<0.05$ (significance)

$\mathrm{r}($ correlation coefficient $)=0.758(75.8 \%)$

Table 5 showed test result of Ki-67 protein expression in NPC with cervical lymphoid node status of N0, negative results were found in 2 NPC patients and positive 1 results were found in 4 NPC patients. In NPC patients with $\mathrm{N} 1$ cervical lymphoid node status, positive 1 result was found in 3 patients and positive 2 result in 2 patients. In NPC patients with N2 cervical lymphoid node status, positive 1 results were founded in 2 patients, positive 2 in 6 patients and positive 3 in 1 patients. In NPC patients with N3 cervical lymphoid node status, positive 1 result was found in 1 patient, positive 2 in 5 patients and positive 3 in 4 patients. Negative value of $\mathrm{Ki}-67$ protein expression was found in 2 patients $(5.71 \%)$ of all samples from NPC patients with cervical lymphoid node status of N0. Expression of Ki-67 protein with positive value was found in 33 samples $(94.29 \%)$ of all samples. Expression of Ki-67 protein with positive value was found in 4 patients with N0 $(11.43 \%), 5$ patients with N1 (14.29\%), 9 patients with N2 (25.71\%), 15 patients with N3 status (42.86\%).

The Spearman test resulted in $\mathrm{P}$ value of 0,0001 and $\mathrm{r}$ (correlation coefficient) value of 0.758 . The data above showed that there was a significant correlation between expression of Ki-67 protein and cervical lymphoid node (N0, N1, N2 and N3) and a strong correlation with correlation coefficient which was at 0.758 (75.8\%) was acquired.

Results from cell proliferation index checking by assessing the expression of $\mathrm{Ki}-67$ using immunohistochemistry technique in NPC tissue were identified with a smear of dark brown colour in the nucleus. Observation and analysis of Ki-67 protein expression by pathologist consultant was done using binocular microscope with 400 times magnification. Results of immunohistochemistry painting were shown in Figure 1 as follow.
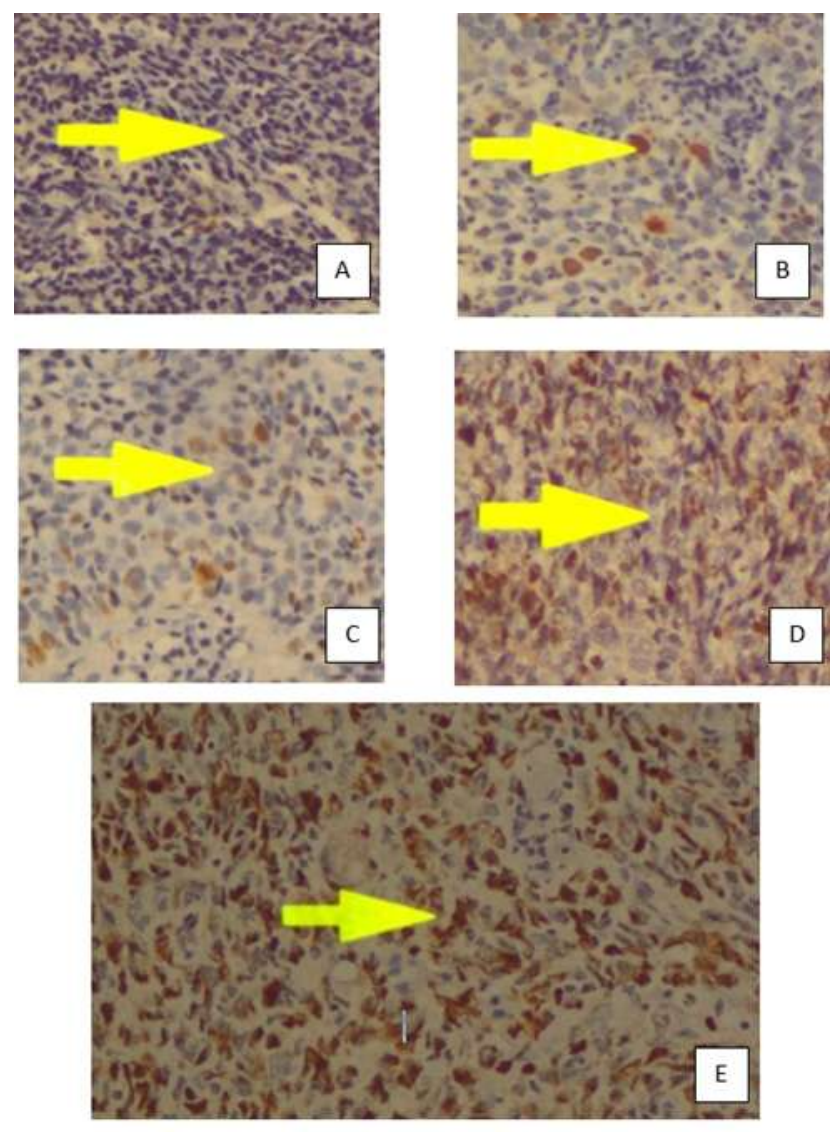

Figure 1. Ki-67 protein painting result in NPC tissue with immunohistochemistry technique, positive expression in the nucleus as brown colored tumor

Notes:

(A) Negative expression of Ki-67 $(<10 \%)$

(B) Positive 1 expression of Ki-67 (10-25\%)

(C) Positive 2 expression of Ki-67 (26-50\%)

(D) Positive 3 expression of Ki-67 (51-75\%)

(E) Positive 4 expression of Ki-67 (>75\%). 
In negative expression of $\mathrm{Ki}-67$, brown smearing in the tumor cell nucleus was not found; yellow arrow show brown smearing in the tumor cell nucleus $(400 \mathrm{x}$ magnification).

\section{DISCUSSION}

This research was performed to analyze the correlation between cell proliferation index assessed from Ki-67 protein expression with cervical lymphoid node status to evaluate cancer cell progressivity and hoped to become alternative to pinpoint therapeutical intervention, progressivity and prognosis of NPC patients. This research only took data from $\mathrm{Ki}-67$ expression checking result to be analyzed statistically without analyzing other factors.

Data of NPC patient distribution based on cervical lymphoid node status was gathered from this research and showed in Table 3. The most abundant cervical lymphoid node status are N3 at 15 patients $(42.86 \%)$, followed by $\mathrm{N} 2$ with 9 patients $(25.71 \%)$. The distribution of NPC patients based on cell proliferation index by evaluating $\mathrm{Ki}-67$ protein expression were shown in Table 4. Ki-67 protein expression with negative results were acquired from 2 patients $(5.71 \%)$ and positive in 33 patients $(94.29 \%)$. Expression of $\mathrm{Ki}$ 67 protein with positive results were acquired from 4 patients with N0 $(11.43 \%), 5$ patients with N1 (14.29\%), 9 patients with N2 $(25.71 \%), 15$ patients with N3 $(42.86 \%)$.

The correlation between cell proliferation index and cervical lymphoid node is shown in Table 5. It shows the $\mathrm{Ki}-67$ protein expression checking result correlated with cervical lymphoid node. The data from the results of the research shows elevation of $\mathrm{Ki}-67$ protein expression followed by cervical lymphoid node enlargement. The data was then analyzed statistically to assess the correlation between cell proliferation index and cervical lymphoid node status using Spearman's test with the following result: $\mathrm{P}$ value at 0.0001 and $\mathrm{r}$ value (correlation coefficient) at 0.758 . The correlation of ki-67 protein expression to assess cell proliferation index with cervical lymphoid node status (N0, N1, N2 and N3) in NPC patients was proven to be significant. The substance from statistical analysis result was the elevation of Ki-67 expression which was connected to the enlargement of cervical lymphoid node and both of the research variable had a strong correlation $(\mathrm{r}=$ 0.758). The expression of $\mathrm{Ki}-67$ protein to assess cell proliferation index could be used to evaluate cancer cell progressivity with cervical lymphoid node enlargement as clinical manifestation can be used as therapeuticalintervention consideration toward NPC patients. Enlargement of cervical lymphoid node was one of the prognostic indicator in NPC patients, in turn Ki-67 expression could become alternative to pinpoint the prognosis of NPC patients. However, prospective research was still need to be conducted to pinpoint the prognostic value with Ki-67 protein in NPC patients.

The result from this research matches with Zhixin and Shaofeng research was conducted in 2002 in Guangxi which studied about the correlation of $\mathrm{Ki}-67$ protein expression to evaluate cell proliferation index in 66 NPC patients has resulted that a significant correlation was acquired between the elevation of cell proliferation index and metastasis. Thus, cell proliferation index could be used as NPC patients prognostic indicator (Zhuxin \& Shaofeng 2013). Shi et al in 2005 conducted a study in to 62 NPC patients, a significant correlation between Ki-67 protein expression and cervical lymphoid node status in NPC patient was acquired, but there was no correlation to cancer stages (Shi et al 2005). Liu et al 2008 conducted a research in Guangzhou toward 43 NPC patients, significant correlation was acquired between $\mathrm{Ki}-67$ protein expression with incident of cervical lymphoid node in NPC patients (Liu et al 2008).

Furthermore, there were also researches with different results. Taweevisit et al in 2010 conducted a study in Thailand to 60 NPC patients, and resulted no significant correlation between cell proliferation index and cervical lymphoid node status in NPC patients (Taweevisit et al 2010). Ozel et al in 2004 conducted a study and acquired no significant correlation between expression of Ki-67 with NPC stages (Ozel et al 2004).

The differences in cell proliferation index by assessing Ki-67 protein expression which in turn connected to cervical lymphoid node status research results may be caused by some reason, because there are factors from NPC patients involved in the research including stadium factor, and type of histopathology; factor of researcher's accuracy in pinpointing the hot spot to assess Ki-67 protein expression; difference in the usage of cell proliferation index assessment standard which was between cut off below $10 \%$ and $30 \%$, when using cut off below $10 \%$, significant result will be gained, unlike when using cut off below 30\% (Taweevisit et al 2010). The expression of $\mathrm{Ki}-67$ protein could be used to assess the accumulation of many carcinogenesis factors. This caused the possibility to estimate progressivity of cancer cell and prognostic; prediction to therapeutical response, pre and post therapy evaluation; and malignancy patients survival rate (Eccles 2011, Harahap 2009).

Some researches that were conducted to study the correlation between cell proliferation index with carcinogenesis process done by researchers. Taweevisit 
(2007) conducted a study to search the correlation of Ki-67 protein expression with mutant p53 protein expression as tumor suppressor protein in 60 NPC patients and get a significant correlation as the result between expression of $\mathrm{Ki}-67$ and mutant p53 proteins. The elevation of p53 tumor supressor protein expression would cause uncontrolled cell proliferation, this was shown by the increase in $\mathrm{Ki}-67$ protein.

Cell proliferation was connected with the mutation of protooncogen into oncogene. This caused malignant tumor to stimulate intracellular growth factor without extracellular stimulation (Eccles 2011). Liu et al (2008) conducted a research to study the correlation between LMP and STAT with cell proliferation in 43 NPC patients in Guangzhou and acquired a significant correlation between $\mathrm{Ki}-67$ protein expression and incident of cervical lymphoid node enlargement in NPC patients.

Ki-67 protein expression to assess cell proliferation index was correlated with cyclin-D1 expression as cell cycle regulator, EGFR and HER2. Hu and Shi (2004) conducted a research to study the correlation between cyclin D1 as cell cycle regulator and $\mathrm{Ki}-67$ protein expression to assess cell proliferation index in 56 NPC patients and acquired significant result, elevation of cyclin-D1 would increase cell proliferation (Tan et al 2005). Ma et al (2003) conducted a research to study the relationship between cell proliferation index, angiogenesis, p53, EGFR and HER2 toward 78 NPC patients and acquired a result which stated that those factors were reciprocal correlation, influencing the clinical condition and prognosis of NPC patients.

Taweevisit et al (2010) conducted a research in Thailand on 60 NPC patients and acquired a significant relationship between microvascular density to evaluate engiogenesis and cell proliferation index which was assessed by expression of $\mathrm{Ki}-67$ protein as the result. They found significant relationship between Ki-67 protein expression and microvascular density with NPC patients' prognostic. Some studies on Ki-67 protein expression were also being used to assess the prognosis of malignancy patients (Eccles 2011). Lavertu et al (2001) conducted a a study on 50 squamous cell malignancy in head and neck and found out that elevation of $\mathrm{Ki} 67$ protein to assess cell proliferation index was significant related with lower survival (Lavertu et al 2001). Taweevisit et al (2010) in Thailand recommended proliferation index by assessing Ki-67 protein expression as the prognostic indicator of NPC patients, because it only required a small amount of tissue to assess the expression of $\mathrm{Ki}-67$ protein.
In short, the expressions of $\mathrm{Ki}-67$ protein were also being used to assess other malignancy prognostic cancer in between them were gall blader malignancy, prostate, breast, endometrium. The evaluation of malignancy patients' prognosis based on $\mathrm{Ki}-67$ protein expression using criterion value of less than $(<) 10 \%$ concluded that the patients had good prognostic, 10\%-25\% indicated medium prognosis, and $>25 \%$ indicated a bad prognosis (Li et al 2008, Lin 2010, Eccles 2011).

\section{CONCLUSION}

This study acquired a significant relationship between cell proliferation index and cervical lymphoid node status in NPC patient with strong correlation. This caused the checking of $\mathrm{Ki}-67$ protein expression to evaluate cell proliferation index to be able to be used as indicator of progressivity, material for interventional therapy, and alternative to pinpoint prognostic factor in NPC patients. Further studies needed to search the correlation between $\mathrm{Ki}-67$ protein expression and kinds of histopathology, stadium, nasopharyngeal primary tumor and metastatic incidence and survival rate in NPC patients. It also needed to compare $\mathrm{Ki}-67$ protein before and after therapy as post therapy assessment and evaluation in NPC patients.

\section{REFERENCES}

Li YH, Hu CF, Shao Q, Huang MY, Hou JH, Xie D (2008). Elevated expressions of survival and VEGF protein are strong independent predictors of survival in advanced nasopharyngeal carcinoma. J Transl Med 6, 1-11.

Taweevisit M, Keelawat S, Thorner PS (2010). Correlation of microvascular density and proliferation index in undifferentiated nasopharyngeal carcinoma. Asian Biomedicine 4, 315-321.

Lin JC (2010). Prognostic factors in nasopharyngeal cancer. In: Lu JJ, Cooper JS, Lee AWM (eds). Nasopharyngeal cancer: multidisciplinary management, Berlin, Springer-Verlag Berlin Heidelberg, p 95-127.

Taweevisit M (2007). Over-expression of p53 and neoplastic cell proliferation in undifferentiated nasopharyngeal carcinoma.Southeast Asian J Trop Med Public Health 38, 136-140.

Eccles SA (2011). Growth regulatory pathway contributing. In: Lyden D, Welch DR, Psaila B (eds). Cancer metastasis: biologic basis and therapeutics, Cambridge, Cambridge University Press, p 55-85.

Kresno SB (2012). Ilmu dasar onkologi, Jakarta, Fakultas Kedokteran Universitas Indonesia, p 1-89. 
Zhuxin W, Shaofeng W (2013). A study on ki67 gene expression and its significance in nasopharyngeal carcinoma. Available from: http://en.cnki.com.cn/Article_en/CJFDTOTALGXYD200206007.htm. Accessed September 11, 2013.

Liu QY, Han AJ, You SY, Dong Y, Yang QY, Wu JH, Li MF (2008). Correlation of Epstein Barr virusencoded latent membrane protein 1 (LMP1) to fascin and phosphorylated Stat3 in nasopharyngeal carcinoma. Ai Zheng 27, 1070-1076.

Shi X, Yuan X, Tao D, Gong J, Hu G (2005). Analysis of DNA poidy, cell cycle and Ki67 antigen in nasopharyngeal carcinoma by flow cytometry. J Huazhong Univ Sci Technolog Med Sci 25, 198-201.

Ozel E, Ozbilim G, Dalmaz MG, Guney K (2004). P53 and $\mathrm{Ki}-67$ expression in nasopharyngeal carcinomas. Turkish Journal of Cancer 34, 106-109.

Piris A, Mihm MC C (2007). Mechanisms of metastasis: seed and soil. In: Leong SPL (eds). Cancer metastasis and lymphovascular system: basis for rational therapy, New York, Springer US, p 119-127.

Aswarin R (2014). Hubungan ekspresi protein p53 mutan dengan status kelenjar getah bening regional pada penderita karsinoma nasofaring tipe III. Dalam: Karya Akhir untuk memperoleh ijazah keahlian Ilmu Kesehatan Telinga Hidung Tenggorok Bedah Kepala dan Leher, Departemen/SMF Ilmu Kesehatan THTKL FK UA/ RSUD Dr Soetomo Surabaya, 2014.

Le QT, Lu JJ (2010). Molecular signaling pathways in nasopharyngeal cancer. In: Lu JJ, Cooper JS, Lee AWM (eds). Nasopharyngeal cancer: multidisciplinary management, Berlin, SpringerVerlag Berlin Haidelberg, p 27-40.

Harahap MPH (2009). Ekspresi vascular endothelial growth factor pada karsinoma nasofaring. Medan, Universitas Sumatra Utara Repository

Medical Records of RSUD Dr Soetomo Surabaya (2014).

National Comprehensive Cancer Network (2011). NCCN clinical practice guideline in oncology (NCCN guideline) head and neck version 2011. Available from:

http://ifile.it/3niy4s/_Abeloff_039_s_Clinical_Oncolo gy_4th_Edition.1_onx341345x98xo9.chm. Accessed September 11, 2013.

Tan PH, Bay BH, Yip G, Selvarajan S, Tan P, Wu J, Lee CH, Li KB (2005). Immunohistochemical detection of $\mathrm{Ki} 67$ in breast cancer correlates with transcriptional regulation of genes related to apoptosis and cell death. Mod Pathol 18, 374-381.

Ma BBY, Poon TCW, Zee B, Mo FKF, Chan CML, Ho S, Teo PML, Johnson PJ, Chan ATC (2003). Prognostic significance of tumor angiogenesis, Ki 67, p53 oncoprotein, epidermal growth factor receptor and HER2 receptor protein expression in undifferentiated nasopharyngeal carcinoma a prospective study. Head Neck 25, 864-872.

Lavertu P, Adelstein DJ, Myles J, Secic M (2001). P53 and $\mathrm{Ki}-67$ as outcome predictors for advanced squamous cell cancers of the head and neck treated with chemoradiotherapy. Laryngoscope 111, 18781892. 